\title{
KONSEP DAN KEPENTINGAN PENGADUAN AWAM DARIPADA PERSPEKTIF ISLAM DAN MODEN: SUATU SOROTAN LITERATUR
}

\section{The Concept and Importance of Public Complaint from Islamic and Modern Perspective: A Literature Review}

\author{
Madihatun Zainuddin ${ }^{1}$ \\ Sharifah Hayaati Syed Ismail ${ }^{2}$
}

\begin{abstract}
This article discusses the concept and importance of public complaints (PC) as a result of a review of 22 literatures (20082019). It aims to identify what are the discussion of $P C$ and how its importance from Islamic and modern perspectives in the literature. Public Complaints (PC) means grievances, comments or suggestions due to a customer s dissatisfaction against public services delivery. It is one of the government essential mechanisms to identify problems and weaknesses in services and to produce best solution. In organization's governance, especially in the century, the community views are important input. There are two main reasons for $P C$ i.e., due to organization failure to provide the best service and also to resolve previous complaints. From the study it is found that the most discussed issues related to PC from
\end{abstract}

\footnotetext{
Ph.D Candidate, Department of Siasah Syar'iyyah, Academy of Islamic Studies, University of Malaya, 50603 Kuala Lumpur, fawarizdi812@gmail.com

2 Associate Professor, Department of Siasah Syar'iyyah, Academy of Islamic Studies, University of Malaya, 50603 Kuala Lumpur, sashsiaq@um.edu.my
} 
Islamic perspective are on three aspects i.e., integrity, customer satisfaction and service quality. PC discussions from modern perspectives are often referred to four aspects include customer satisfaction, quality of service, the value of integrity and the need for continuous improvement. Literature review also found that an effective complaint handling system is important to create quality public service. The basis for Islamic literature discussions is from the Qur'ān, al-Hadīth, the concept of al-shūrā, amar ma 'rūf nahī munkar, mașlahah, maqāṣid al-sharī'ah, the value of trust and the views of scholars include Karim Zaidan, 'Abd al-Wahhāb Khallāf, al-Baydawī and Raja Ali Haji. All 22 literatures agreed on the importance of PC in service delivery and the need for it to be resolved effectively. The literature also found that the lesser the PC the higher the service quality. And success in dealing with $P C$ shows service provider commitment that can lead to a good service delivery culture.

Keywords: public complaint, customer satisfaction, service delivery, integrity, al-shura

\section{PENDAHULUAN}

Dalam mentadbir organisasi, salah satu mekanisme untuk memperolehi hasil perkhidmatan yang terbaik adalah dengan mendapatkan maklum balas daripada pelanggan atau masyarakat awam. Pengaduan awam (PA) adalah salah satu bentuk maklum balas yang akan membuka ruang kepada penyedia perkhidmatan untuk melihat semula perkhidmatan yang telah diberikan sama ada ia memuaskan atau sebaliknya. PA yang disampaikan oleh masyarakat, merupakan input dalam proses "semak dan imbang" dalam perkhidmatan awam atau dari perspektif Islam dikategorikan sebagai suatu proses amar ma 'rüf nahī munkar. ${ }^{3}$ Ia juga membuka ruang untuk cadangan penambahbaikan yang merupakan proses utama bagi mencapai kecemerlangan perkhidmatan dan tadbir urus. Tujuan utama PA adalah bagi memastikan tadbir urus sesebuah organisasi atau negara dijalankan dengan lancar dan berkesan seiring dengan kemaslahatan masyarakat. Amalan untuk mencapai kemaslahatan adalah usaha yang baik dan amat dituntut dalam ajaran Islam, sepertimana dalam firmanNya di dalam al-Quran:

\footnotetext{
3 Mujar Ibnu Syarif, 'Pengaduan Awam Menurut Perspektif Politik Islam,' dalam Pengurusan Aduan Menurut Islam, ed. Siti Arni Basir (Shah Alam: Institut Perkembangan Minda (INMIND), 2012), 1-30.
} 


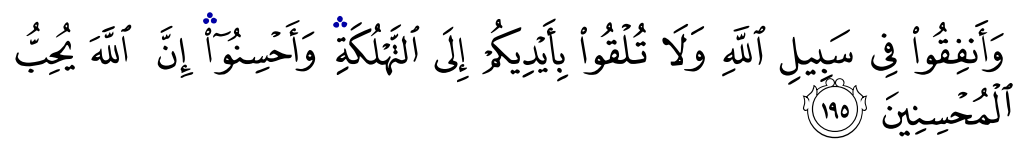

"Dan belanjakanlah (harta bendamu) di jalan Allah, dan janganlah kamu menjatuhkan dirimu sendiri ke dalam kebinasaan, dan berbuat baiklah, kerana sesungguhnya Allah menyukai orang-orang yang berbuat baik."

(Surah al-Baqarah, 2: 195)

Pengaduan awam dalam sesebuah organisasi bermaksud satu ekspresi ketidakpuashatian orang ramai terhadap mutu, kualiti atau layanan perkhidmatan yang diterima sama ada daripada penjawat awam atau perkhidmatan sesebuah agensi. ${ }^{4}$ Justeru, dalam merealisasikan budaya kerja yang cemerlang, aspek penambahbaikan antaranya dengan mendapatkan maklum balas melalui PA yang diterima. ${ }^{5}$ Bahkan ia juga ukuran kepada sama ada wujudnya kepuasan pelanggan (KP) yang tinggi atau tidak terhadap perkhidmatan. ${ }^{6}$ Kepentingan terhadap memenuhi KP ini didorong oleh kehendak mereka yang semakin meningkat dan berubah ekoran kesedaran dan kemudahan teknologi masa kini. $^{7}$

\section{KONSEP PENGADUAN AWAM MENURUT PERSPEKTIF ISLAM}

Islam amat menggalakkan umatnya berusaha untuk melaksanakan sesuatu tindakan dengan hasil yang terbaik, iaitu untuk memenuhi kepentingan agama, masyarakat dan organisasi selaras dengan konsep mașlahah dan untuk menghindarkan mafsadah. ${ }^{8}$ Mașlaḥah merupakan satu konsep yang

$4 \quad$ Nik Hairi Omar, Azmi Awang \& Azmi Abdul Manaf, 'Integriti Dari Perspektif Pengaduan Awam: Kajian Kes di Jabatan Pengangkutan Jalan (JPJ) Malaysia,' e-BANGI: Jurnal Sains Sosial dan Kemanusiaan, vol. 7/1 (2012): 141-155.

5 Sharifah Hayaati Syed Ismail, 'Budaya Kerja Cemerlang Menurut Perspektif Islam: Amalan Perkhidmatan Awam Malaysia,' Jurnal Pengajian Melayu, vol. 19/1 (2008): 187-207.

$6 \quad$ Siti Arni Basir \& Musaiyadah Ahmadun, 'Prinsip-Prinsip Pengurusan Pengaduan Awam Dari Perspektif Islam,' dalam Pengurusan Aduan Menurut Islam, ed. Siti Arni Basir (Shah Alam: Institut Perkembangan Minda (INMIND), 2012), 59-82.

7 Zikri Muhammad, Tarmiji Masron \& Aziz A. Majid, 'Local Government Service Efficiency: Public Participation Matters,' International Journal of Social Science and Humanity, vol. 5/10 (2015): 825.

8 Sharifah Hayaati Syed Ismail \& Nor 'Azzah Kamri, 'Teras Pengurusan Islam,' dalam Pengurusan Aduan Menurut Islam, ed. Siti Arni Basir (Shah Alam: Institut Perkembangan Minda (INMIND), 2012), 31-57. 
menitikberatkan persoalan kebajikan masyarakat. Tuntutan secara umum tentang keperluan menjaga mașlaḥah ini juga dibahaskan dalam kaedah yang dinamakan 'mașāliḥ al-mursalah', ' iaitu apa juga perkara yang bertujuan menjaga kepentingan-kepentingan awam walaupun ia tidak dinyatakan secara jelas dan khusus dalam al-Quran atau Sunnah. ${ }^{10}$ Konsep PA dalam Islam adalah salah satu amalan yang membawa matlamat maṣlaḥah dan menghindarkan mafsadah dalam organisasi.

Menurut Karim Zaidan ${ }^{11}$ menyampaikan aduan kepada pentadbir atau pemerintah adalah diharuskan. Ia merupakan hak masyarakat dan terpulang kepada mereka untuk menyuarakan kehendaknya kepada kerajaan. Dalam ilmu pemerintahan Islam, rakyat yang merupakan pelanggan dibenarkan membuat cadangan, komen atau rungutan kepada kerajaan atau pihak atasan selagi ianya tidak bertentangan dengan prinsip syarak. Dalam Islam, aduan dan komen rakyat juga dijadikan sumber kepada tindakan kerajaan dalam membentuk dasar, peraturan dan polisi negara. ${ }^{12}$ Manakala menurut 'Abd alWahhāb Khallāf, ${ }^{13}$ hukum membuat pengaduan awam adalah fardhu kifayah, iaitu jika ada orang lain atau pihak yang tertentu yang telah membuat aduan, maka sebahagian umat Islam yang lain yang tidak membuatnya akan terlepas daripada tanggungjawab tersebut dan tidak berdosa. Namun, jika tiada seorang pun yang membuat aduan, maka seluruh umat Islam itu dikira berdosa kerana gagal melaksanakan teguran. Ini kerana ia termasuk dalam perkara amar ma ' $r u \bar{f}$ nahī munkar. ${ }^{14} \mathrm{PA}$ dilakukan oleh masyarakat adalah disebabkan oleh pelbagai faktor. Di antaranya kerana kegagalan organisasi menyediakan perkhidmatan yang terbaik dan juga disebabkan kegagalan organisasi untuk menyelesaikan aduan terdahulu yang dikemukakan. ${ }^{15}$

9 Al-Shātibī, al-I tișām min al-Kutub, vol. 3 (Qāhirah: al-Maktabah al-Tijāriyyah al-Kubrā, 1975), 59.

10 Al-Shāțibī, al-I'tiṣām min al-Kutub, vol. 3, 59. Lihat juga: Muhammad Asad, The Principles of State and Government in Islam (Gibraltar: Dar al-Andalus, 1985), 43-44.

11 Karim Zaidan, Masalah Kenegaraan dalam Pandangan Islam (Jakarta: Yayasan al-Amin, 1984), 94.

12 Bharuddin Che' Pa, 'Pengaduan Awam di Malaysia Menurut Perspektif Siasah Syar'iyyah,' dalam Pengurusan Aduan Menurut Islam, ed. Siti Arni Basir (Shah Alam: Institut Perkembangan Minda (INMIND), 2012), 83-105.

13 'Abd al-Wahhāb Khallāf, 'Ilm Ușūl al-Fiqh (Kuwait: Dār al-Qalam, 1978), 105.

14 'Abd al-Wahhāb Khallāf, 'Ilm Ușūl al-Fiqh, 105.

15 Magatef, Sima Ghaleb, Raed Ahmad Momani \& Ghaiath Altrjman, 'The Evaluation of Complaint Handling Process in Five Star Hotels and its Reflection on Customers' Satisfaction,' African Journal of Hospitality, Tourism and Leisure, vol. 8/2 (2019): 1-21. 
Di samping itu, PA adalah sebagai kaedah atau al-wasilah bagi memenuhi matlamat Syariah. Matlamat Syariah merangkumi tujuan untuk memelihara agama, akal, harta, keturunan dan nyawa. ${ }^{16}$ Malah, menurut al-Bayḍawī, ${ }^{17}$ al-wasilah ialah sesuatu perantaraan yang boleh mendatangkan pahala dan mendekatkan diri seseorang kepada Allah SWT. Justeru, PA daripada perspektif Islam berkaitrapat dengan kewajipan melaksanakan perkhidmatan berteraskan nilai tanggungjawab dan amanah atau integriti oleh penyedia perkhidmatan dalam sesebuah organisasi dan negara. Sifat ini membentuk akhlak pekerja yang kukuh (matīn al-khulūq). ${ }^{18}$ Matīn al-khulūq merupakan sikap dan perilaku yang mesti dimiliki oleh setiap Muslim, baik dalam hubungannya dengan Allah SWT mahupun hubungan sesama makhluk. Dalam konteks pekerjaan, setiap individu yang memiliki keperibadian Islam mestilah tidak meninggalkan tanggungjawab pekerjaan, jujur, amanah, ikhlas dan tekun menunaikan tanggungjawab. Amalan tingkah laku integriti ini merupakan titik penting dalam menentukan lonjakan kualiti perkhidmatan ke arah usaha peningkatan, penambahbaikan perkhidmatan dan melaksanakan tindakan pembetulan berterusan. ${ }^{19}$ Bahkan dengan akhlak yang mulia, manusia akan bahagia dalam hidupnya, di dunia dan akhirat. Firman Allah SWT di dalam al-Quran:

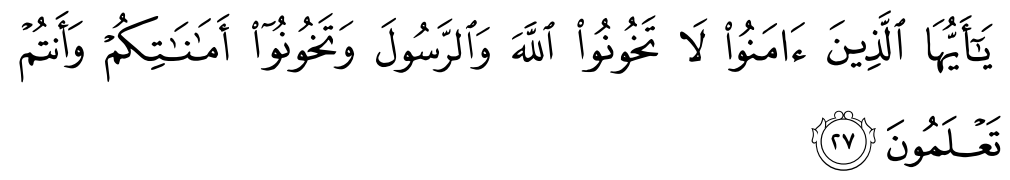

"Wahai orang-orang yang beriman! janganlah kamu mengkhianati (amanah) Allah dan RasulNya, dan (janganlah) kamu mengkhianati amanah-amanah kamu, sedang kamu mengetahui (salahnya)."

(Surah al-Anfāl, 8: 27)

16 'Abd al-Wahhāb Khallāf, 'Ilm Ușūl al-Fiqh, 105.

17 Abū Sa'īe 'Abd Allāh Ibn 'Umar Ibn Muhammad al-Shīrazī al-Bayḍawī, Tafsīr al-Bayḍ̂ū al-Musammā Anwār al-Tanzīl wa Asrār al-Ta'wūl, vol. 1 (Bayrūt: Dār al-Kutub al-'Ilmiyyah, 1988), 265.

18 Hasan al-Banna, Majmū'ah al-Rasā'il li al-Imām al-Shāhid Hasan al-Banna (Bayrūt: Dār al-Qalam, 1974), 438; Hasan al-Banna, Risalah Pergerakan Ikhwan al-Muslimin (Solo: Intermedia, 2005), 168-169.

19 Kamaruddin Musa, Norizan Saad \& Mohd Asri Mohd Nor, 'Tingkah Laku Integriti dalam Pemantapan Pengurusan Sektor Perkhidmatan Awam,' Management Research Journal, vol. 7 (2018): 260-277. 


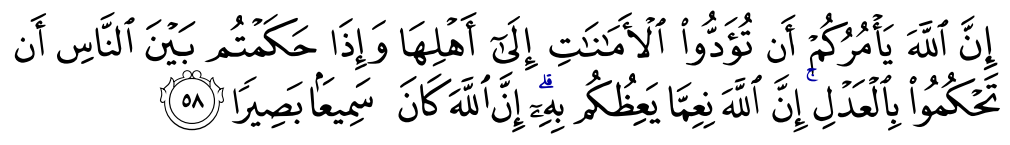

"Sesungguhnya Allah menyuruh kamu supaya menyerahkan segala jenis amanah kepada ahlinya (yang berhak menerimanya), dan apabila kamu menjalankan hukum di antara manusia, (Allah menyuruh) kamu menghukum dengan adil. Sesungguhnya Allah dengan (suruhanNya) itu memberi pengajaran yang sebaikbaiknya kepada kamu. Sesungguhnya Allah sentiasa Mendengar, lagi sentiasa Melihat."

(Surah al-Nisā', 4: 58)

Oleh itu, nilai amanah adalah aspek yang penting bagi membangunkan rasa bertanggungjawab dalam menyelesaikan aduan awam bagi memastikan mașlahah awam terjaga dalam organisasi, ${ }^{20}$ kerana tiada yang dapat mengubah keadaan buruk sesuatu kaum jika mereka tidak mengubahnya. Firman Allah SWT di dalam al-Quran:

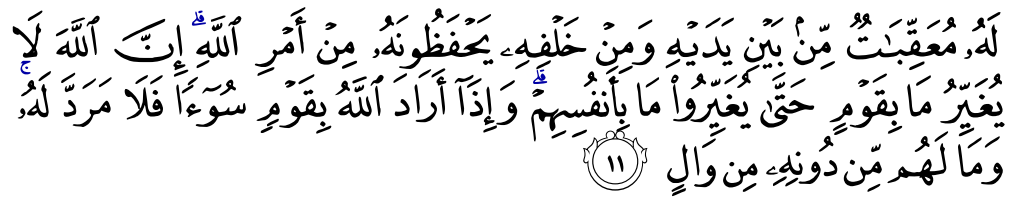

"Sesungguhnya Allah tidak mengubah apa yang ada pada sesuatu kaum sehingga mereka mengubah apa yang ada pada diri mereka sendiri. dan apabila Allah menghendaki untuk menimpakan kepada sesuatu kaum bala bencana (disebabkan kesalahan mereka sendiri)."

(Surah al-Ra'd, 13: 11)

Melalui mekanisme PA, penjawat awam akan dapat menjaga tingkah lakunya dalam menjalankan kerja. Secara tidak langsung, proses sebegini akan membentuk nilai, adab dan akhlak yang baik dan seterusnya akan mewujudnya satu bentuk budaya kerja yang beramanah dan berintegriti. ${ }^{21}$ Secara ringkasnya,

20 Mohammad Ghozali \& Nor 'Azzah Kamri, 'Keperibadian Islam dan Profesionalisme dalam Pekerjaan: Satu Analisis Teoritis,' Jurnal Syariah, vol. 23/2 (2015): 255-286.

21 Ridzuan Masri, Arman Ahmad \& Razlina Abd Rani, 'Teori Maslow dalam Konteks Memenuhi Keperluan Asas Pekerja dan Peranannya dalam Meningkatkan Prestasi Organisasi: Kajian dan Perspektif Islam,' Jurnal Hadhari, vol. 10, no. 1 (2018): $1-27$. 
pengurusan PA boleh membentuk budaya organisasi berprestasi. Bahkan, ajaran Islam tidak menolak sebaliknya menggalakkan apa jua usaha yang membawa kepada komitmen perkhidmatan yang berintegriti selagi ia tidak bertentangan dengan syariat Islam. ${ }^{22}$

Selain kepentingan menyediakan saluran PA melalui konsep asas amar ma'rūf nahī munkar dan pelaksanaan nilai amanah perkhidmatan yang telah dibincangkan di atas, PA juga telah dibincangkan dalam penulisan berkaitan pemerintahan kerajaan Melayu silam. Sebagai contohnya, Raja Ali Haji, seorang cendekiawan dan pembesar dalam kesultanan Johor-RiauLingga telah mengutarakan konsep PA ini dalam penulisannya yang bertajuk Muqaddimah fil Intizam. ${ }^{23}$ Raja Ali Haji seorang pemerintah yang Islamik telah memperkenalkan konsep aduan pada zaman pemerintahan beliau. Beliau mengkelaskan aduan dari tiga kategori (Raja Ali Haji, 1304H):

a) Aduan bangsa Malaikat

b) Aduan bangsa hawa nafsu

c) Aduan bangsa syaitan

Beliau menjelaskan aduan dibuat mengikut tiga kategori manusia yang membuat aduan. Contohnya beliau menjelaskan aduan dari kategori bangsa Malaikat. Tokoh cendekiawan ini menyatakan bahawa aduan yang betul adalah aduan yang menepati syariat Islam dan kesan ataupun tujuan aduan dilakukan adalah untuk memberikan kebaikan di dunia dan pahala yang besar di sisi Allah SWT. ${ }^{24}$ Maksud aduan yang dinyatakan ini diambil berdasarkan kata-kata beliau ini yang disandarkan kepada bangsa Malaikat (Raja Ali Haji, $1304 \mathrm{H})$ :

"Adapun alamat bangsa malaikat berbunyian serta berbetulan serta berbetulan di dalam syariat adapun akibatnya kembali Sa'adah al-Dunya wa al-Akhirah yakni keuntungan di dunia dan

22 Ridzuan Masri, Arman Ahmad \& Razlina Abd Rani, ‘Teori Maslow dalam Konteks Memenuhi Keperluan Asas Pekerja dan Peranannya dalam Meningkatkan Prestasi Organisasi: Kajian dan Perspektif Islam,' 1-27.

23 Raja Hishamuddin Raja Sulong, 'Pengaduan Awam Pada Pandangan Cendiakawan Melayu di Zaman Kesultanan Melayu Johor-Riau-Lingga: Fokus Kepada Raja Ali Haji,' dalam Pengurusan Aduan Menurut Islam, ed. Siti Arni Basir (Shah Alam: Institut Perkembangan Minda (INMIND), 2012), 147-175.

24 Raja Hishamuddin Raja Sulong, 'Pengaduan Awam Pada Pandangan Cendiakawan Melayu di Zaman Kesultanan Melayu Johor-Riau-Lingga: Fokus Kepada Raja Ali Haji,' 147-175. 
keuntungan akhirat." 25

Menurut Raja Ali Haji, aduan yang diterima harus disiasat dan diteliti dengan sebetulnya supaya kezaliman dan tindakan salah urus dapat dielakkan. Dengan ini, kebajikan rakyat akan terbela dan keyakinan rakyat terhadap kemampuan pemerintah akan bertambah. ${ }^{26}$ Tambahan pula, mereka yang menyampaikan aduan tersebut terdiri daripada manusia yang mempunyai karakter dan personaliti yang berbeza seperti yang beliau kategorikan di atas.

\section{$A L-S H \bar{U} R \bar{A}$ SEBAGAI MEKANISME PENGADUAN AWAM DALAM ISLAM}

Islam menawarkan konsep al-shūrā sebagai salah satu mekanisme untuk mendapatkan maklum balas, mengurus pentadbiran, mengurangkan bebanan yang dipikul oleh pemimpin dan mewujudkan kata sepakat dalam apa juga urusan yang melibatkan masyarakat. ${ }^{27}$ Sehubungan dengan itu, masyarakat diberikan peluang untuk bersuara termasuk untuk menyuarakan perkaraperkara yang tidak memuaskan hati mereka. Kepentingan al-shūrā sebagai mekanisme PA dapat dilihat apabila ajaran Islam menyeru kepada budaya tegur-menegur dan nasihat-menasihati. Budaya tegur menegur dan nasihat menasihati ini mengandungi falsafah dan kepentingan yang terkandung dalam konsep PA yang diamalkan dalam mana-mana tadbir urus negara mahu pun organisasi. ${ }^{28}$ Kaedah ini juga mengenengahkan semangat permuafakatan dan boleh mengurangkan kecenderungan memutuskan keputusan bagi kepentingan peribadi. ${ }^{29}$ Sabda Rasulullah SAW:

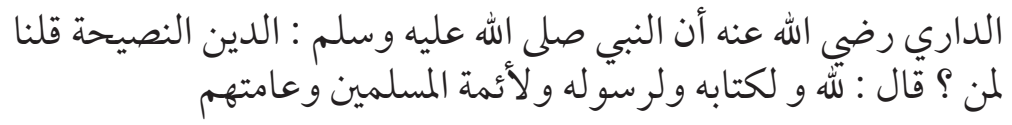

25 Raja Hishamuddin Raja Sulong, 'Pengaduan Awam Pada Pandangan Cendiakawan Melayu di Zaman Kesultanan Melayu Johor-Riau-Lingga: Fokus Kepada Raja Ali Haji,' 147-175.

26 Raja Hishamuddin Raja Sulong, 'Pengaduan Awam Pada Pandangan Cendiakawan Melayu di Zaman Kesultanan Melayu Johor-Riau-Lingga: Fokus Kepada Raja Ali Haji,' $147-175$.

27 Mohamad Zaidi Abdul Rahman, 'Kebebasan Bersuara Dari Perspektif Siasah Syar'iyah,' Jurnal Syariah, vol. 9/2 (2001): 103-122.

28 Hasan Al-Banna Mohamed, Ab Mumin Ab Ghani \& Siti Arni Basir, 'NilaiNilai Sistem Pengurusan Kualiti Islam Berasaskan al-Quran dan Integrasi Ilmu Saintifik,' Jurnal Syariah, vol. 23/1 (2015): 25-52.

29 Muhammad Asad, The Principles of State and Government in Islam, 43-44. 
"Dari Abu Ruqayyah Tamim bin Aws al-Dari RA, bahawasanya Nabi SAW bersabda: Agama itu nasihat: kami berkata bagi siapa? Baginda bersabda: bagi Allah dan bagi kitabnya dan bagi RasulNya dan imam-imam kaum Muslimin dan bagi orang ramai." 30

Manakala firman Allah SWT agar melaksanakan al-shūrā sebagaimana berikut:

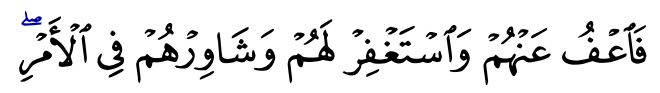

"Oleh itu maafkanlah mereka (mengenai kesalahan yang mereka lakukan terhadapmu) dan pohonkanlah ampun bagi mereka dan juga bermesyuaratlah dengan mereka dalam urusan (peperangan dan hal-hal keduniaan) itu."

(Surah Āli-'Imrān, 3: 159)

Seterusnya Allah SWT berfirman di dalam al-Quran:

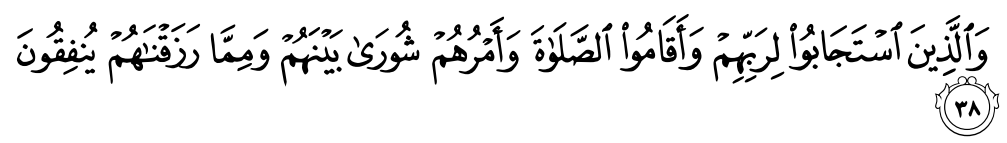

"Dan juga (lebih baik dan lebih kekal bagi) orang-orang yang menyahut dan menyambut perintah Tuhannya serta mendirikan sembahyang dengan sempurna dan urusan mereka dijalankan secara bermesyuarat sesama mereka dan mereka pula mendermakan sebahagian dari apa yang Kami beri kepadanya."

(Surah al-Shūrā, 42: 38)

Pada zaman Rasulullah SAW al-shūrā merupakan suatu saluran untuk melontarkan aduan, pandangan atau cadangan. Contohnya apabila Seorang lelaki telah datang membuat aduan kepada Rasulullah SAW tentang kejahatan jirannya yang selalu mengancam keluarganya. Rasulullah SAW menyuruh lelaki berkenaan memunggah barang-barang yang terdapat di dalam rumahnya ke jalan raya. Lalu lelaki berkenaan telah memunggah barang-barangnya itu dan meletakkannya di atas jalan raya. Kemudian mereka yang menggunakan

30 Hadis riwayat Muslim. Lihat Shaykh Muhammad Ibn Șāliḥ al-'Uthaymīn, Sharh al-Arba'in al-Nawawiyyah, terj. Abu Ahsan Sirojuddin Hasan Bashri (Jakarta: Pustaka Ibnu Kathir, 2009), 182. 
jalan raya tersebut bertanya lelaki itu mengapa beliau berbuat demikian. Beliau menjelaskan bahawa Rasulullah SAW mencadangkan beliau berbuat demikian bagi mengatasi kejahatan jirannya. Apabila mendengar penjelasan tersebut, orang ramai yang lalu di situ mengutuk dan melaknat jiran yang jahat itu. Akhirnya perkara tersebut sampai kepada pengetahuan jiran tersebut. Beliau segera menemui lelaki berkenaan dan meminta supaya membawa pulang barang-barangnya itu seraya berkata: Demi Allah saya tidak akan mengganggu kamu lagi. ${ }^{31}$

\section{KONSEP PENGADUAN AWAM MENURUT PERSPEKTIF MODEN}

Perbincangan tentang PA dalam literatur menurut perspektif moden juga telah mengaitkannya dengan kepuasan pelanggan (KP1), kualiti perkhidmatan (KP2), nilai integriti (NI) dan keperluan terhadap usaha penambahbaikan berterusan (PB) dalam organisasi. PA adalah satu ekspresi ketidakpuashatian orang ramai terhadap mutu, kualiti atau layanan perkhidmatan yang diterima daripada penjawat awam atau sesebuah agensi. Peningkatan PA secara teknikal menunjukkan kemerosotan tahap integriti khasnya apabila pengaduan yang direkod dan disiasat mempunyai merit. ${ }^{32}$ Walau bagaimanapun, menerima aduan daripada pelanggan adalah sesuatu yang lumrah. Ini bererti PA adalah luahan pelanggan atau rasa tidak puas hati mereka sama ada terhadap kualiti perkhidmatan mahupun produk yang diterima. Ia disuarakan sama ada dalam bentuk komen atau kritikan. Menurut Murdifin Haming et al., perkhidmatan berkualiti yang diberikan kepada pelanggan merupakan kesan yang besar untuk mendapatkan KP1.33

31 Abū Dāwud, Sunan Abū Dāwud, vol. 4 (Bayrūt: Dār al-Fikr, t.t.), 339; Lihat juga Abī 'Abd Allāh Muḥammad Ibn Abī Bakr Shams al-Dīn Ibn al-Qayyim al-Jawziyyah, Țruq al-Hukmiyyah fì al-Siyāsah al-Shar 'iyyah (Bayrūt: Dār alKutub al-'Ilmiyyah, 1995), 27.

32 Nik Hairi Omar, Azmi Awang \& Azmi Abdul Manaf, 'Integriti Dari Perspektif Pengaduan Awam: Kajian Kes di Jabatan Pengangkutan Jalan (JPJ) Malaysia,' 141-155.

33 Haming, Murdifin, Imaduddin Murdifin, A. Zulfikar Syaiful \& Aditya Halim Perdana Kusuma Putra, 'The Application of SERVQUAL Distribution in Measuring Customer Satisfaction of Retails Company,' Journal of Distribution Science (2019): 25-34. 
Selain itu, menurut Shatina Saad dan Muhamad Halim Nizarwan, ${ }^{34}$ kualiti perkhidmatan (KP2) dapat diukur melalui jumlah aduan pelanggan yang diterima. Semakin rendah aduan, semakin tinggi KP2 diberikan. Pengalaman positif di antara pelanggan dan organisasi dapat mengurangkan PA dan kesan negatif dalam menangani aduan mereka. ${ }^{35}$ Menurut Kotler dan Keller KP1 merupakan perasaan yang membahagiakan, menggembirakan atau perasaan kekecewaan akibat perkhidmatan yang tidak dicapai oleh jangkaannya. Tetapi apabila perkhidmatan mencapai jangkaan pelanggan, tahap tertinggi kepuasan hati mereka akan tercapai. ${ }^{36}$ Penentu utama kepada KP1 ialah jangkaan mengenai produk atau perkhidmatan dari aspek ciri-ciri, faedah, kosnya dan tahap KP2 yang merupakan prestasi sebenar. ${ }^{37}$ Dengan kata lain, KP1 diperolehi setelah pelanggan mendapati perkhidmatan atau produk yang diberikan oleh sesebuah organisasi memuaskan dari segala aspek yang dikehendaki pelanggan dan perkara itu menunjukkan bahawa organisasi telah mencapai tahap prestasi yang positif dalam berurusan dengan pelanggan. ${ }^{38}$ KP1 merupakan hasil akhir daripada proses PA yang dijalankan dalam sebuah pentadbiran mahupun organisasi. ${ }^{39}$

Perbincangan PA juga menekankan kepada bagaimana menguruskannya secara sistematik dan efektif bagi menghasilkan KP2. Sistem pengendalian

34 Saad, Shatina \& Muhamad Halim Nizarwan, 'Complaint Management in Public Services: A Case Study at Local District Municipal Authority in Malaysia,' (Proceedings of Knowledge Management International Conference (KMICe), Chiang Mai, Thailand, 29-30 August 2016), 44.

35 Rashad Abdel Monim Mohamed, 'The Method of Handling Customers' Complaints and its Role in Defining Programs of Relations Marketing,' Egyptian Journal of Commercial Studies, vol. 30/2 (2006): 467-555.

36 Kotler, P.T. \& Keller, K.L., Marketing Management (Harlow: Pearson Education Limited, 2016).

37 The Saudi Investment Bank, Sustainability Report (Saudi Arabia: The Saudi Investment Bank, 2013).

38 Zakaria, Zaherawati, Kamarudin Ngah, Nazni Noordin \& Mohd Zool Hilmie Mohamed, 'The Impact of Collection and Dissemination of Information towards Public Complaint on Municipal Services,' (Proceedings of Knowledge Management International Conference (KMICe), Chiang Mai, Thailand, 29-30 August 2016), 44.

39 Magatef, Sima Ghaleb, Raed Ahmad Momani \& Ghaiath Altrjman, 'The Evaluation of Complaint Handling Process in Five Star Hotels and its Reflection on Customers' Satisfaction,' 11. 
aduan yang berkesan adalah penting untuk mewujudkan perkhidmatan awam yang berkualiti. ${ }^{40}$ Menurut Siba et al. pengendalian PA yang sistematik melibatkan tiga proses berikut; ${ }^{41}$

a) Membuat rancangan untuk menyiasat aduan

b) Menjawab aduan

c) Membuat susulan aduan

Ia sejajar dengan keperluan terhadap penambahbaikan berterusan (PB) yang perlu dilakukan setelah mengenal pasti kelemahan-kelemahan tertentu dalam pentadbiran organisasi mahupun negara hasil daripada PA yang diterima. Salah satu ciri pengurusan aduan yang berkesan adalah kecekapan. Kecekapan adalah penggunaan input minimum tetapi menghasilkan output maksimum. ${ }^{42}$ Antara proses pengendalian PA yang cekap meliputi usaha berikut; ${ }^{43}$

a) Mengenal pasti dengan jelas bentuk aduan

b) Menentukan langkah yang disusun untuk menyiasat aduan yang diterima

c) Menentukan tempoh masa untuk menyelesaikannya

d) Merekodkan aduan

Selain daripada itu, konsep PA daripada perspektif moden turun dikaitkan dengan nilai integriti, iaitu sejauh mana perkhidmatan dan produk yang diberikan telah disampaikan dengan cara dan nilai yang baik kepada pelanggan. ${ }^{44}$ Integriti merupakan satu nilai amalan yang amat penting bagi sesebuah

40 Mantaring, Allan V., Ma Angela P. Espinoza \& Arneil G. Gabriel, 'Complaint Management in the Public Sector Organization in the Philippines,' Public Policy and Administration Research, vol. 9/2 (2019): 1-26.

41 Magatef, Sima Ghaleb, Raed Ahmad Momani \& Ghaiath Altrjman, 'The Evaluation of Complaint Handling Process in Five Star Hotels and its Reflection on Customers' Satisfaction,' 9-10.

42 Erkoc T.E., 'Bureaucracy and Efficiency,' in Global Encyclopedia of Public Administration, Public Policy, and Governance, ed. Farazmand A. (Cham: Springer, 2017), 1-2.

43 Magatef, Sima Ghaleb, Raed Ahmad Momani \& Ghaiath Altrjman, 'The Evaluation of Complaint Handling Process in Five Star Hotels and its Reflection on Customers' Satisfaction,' 1-21.

44 Sulaiman, Wan Idros Wan, Nurfarhah Othman \& Maizatul Haizan Mahbob, 'Hubungan Pengkomunikasian Budaya Organisasi Dengan Prestasi Kerja Kakitangan Pelaksana Sektor Awam,' e-Bangi, vol. 14, no. 3 (2018): 1-18. 
organisasi dalam mencorakkan budaya organisasi ${ }^{45}$ Ia berperanan sebagai penanda aras kepada tahap kebolehpercayaan, kecekapan, dan keberkesanan organisasi yang diperoleh daripada maklum balas dan persepsi pelanggan terhadapnya. ${ }^{46}$ Dalam konteks PA ia juga digunakan sebagai kayu pengukur kepada pencapaian tahap integriti kakitangan dalam sesebuah organisasi. ${ }^{47}$

Dapat disimpulkan wujud perkaitan yang erat antara konsep dan kepentingan PA dengan pengurusan aduan, kepuasan pelanggan, integriti, perkhidmatan berkualiti dan penambahbaikan berterusan. PA memainkan peranan sebagai 'check and balance' dan juga sistem pemantauan yang berkesan. Ia akan membantu melancarkan pelaksanaan sesuatu tadbir urus. Perkara ini akan menyebabkan tahap KP2 akan meningkat dengan meningkatnya KP1. Seterusnya, prestasi sesebuah organisasi juga turut meningkat dengan meningkatnya NI dan usaha ke arah PB. Hasilnya, perkhidmatan yang disampaikan adalah kompetitif. ${ }^{48}$ Justeru, hasil penelitian terhadap perbincangan konsep dan kepentingan PA menurut perspektif Islam dan moden, maka rumusan literatur yang telah dilakukan adalah seperti jadual berikut:

45 Megat Ayop Megat Arifin \& Abd Halim Ahmad, 'Konsep Integriti dalam Organisasi Polis Diraja Malaysia (PDRM): Satu Tinjauan Awal,' GeografiaMalaysian Journal of Society and Space, vol. 12/8 (2017): 136-147

46 Megat Ayop Megat Arifin \& Abd Halim Ahmad, 'Konsep Integriti dalam Organisasi Polis Diraja Malaysia (PDRM): Satu Tinjauan Awal,' 136-147.

47 Ridzuan Masri, Arman Ahmad \& Razlina Abd Rani, 'Teori Maslow dalam Konteks Memenuhi Keperluan Asas Pekerja dan Peranannya dalam Meningkatkan Prestasi Organisasi: Kajian dan Perspektif Islam,' 1-27.

48 Ilhamie Abdul Ghani Azmi, 'Amalan Pengaduan Awam di Malaysia,' dalam Pengurusan Aduan Menurut Islam, ed. Siti Arni Basir (Shah Alam: Institut Perkembangan Minda (INMIND), 2012), 127-146. 
Jurnal Syariah, Jil. 28, Bil. 1 (2020) 31-54

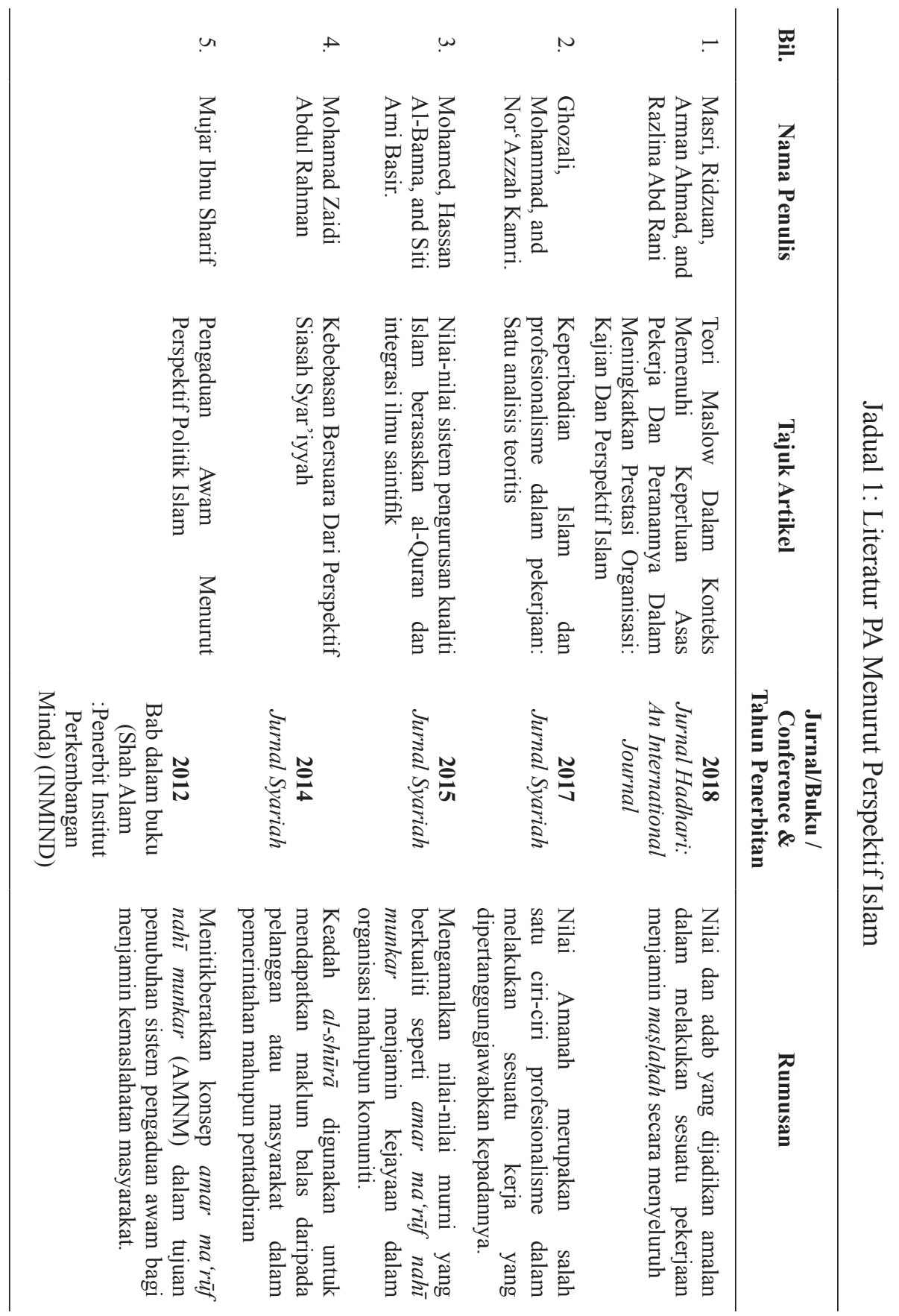


Konsep dan Kepentingan Pengaduan Awam daripada Perspektif Islam dan Moden: Suatu Sorotan Literatur

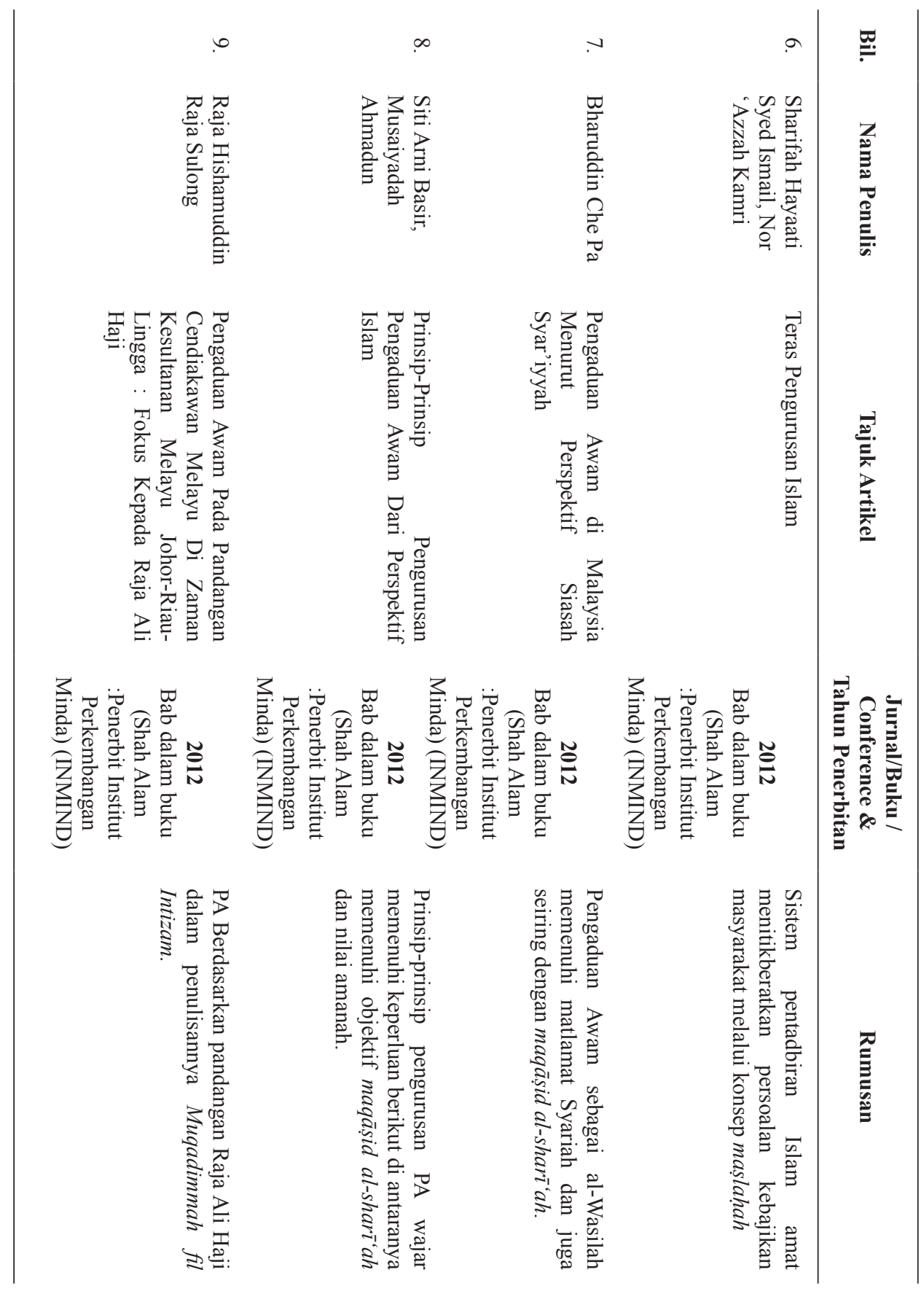


Jurnal Syariah, Jil. 28, Bil. 1 (2020) 31-54

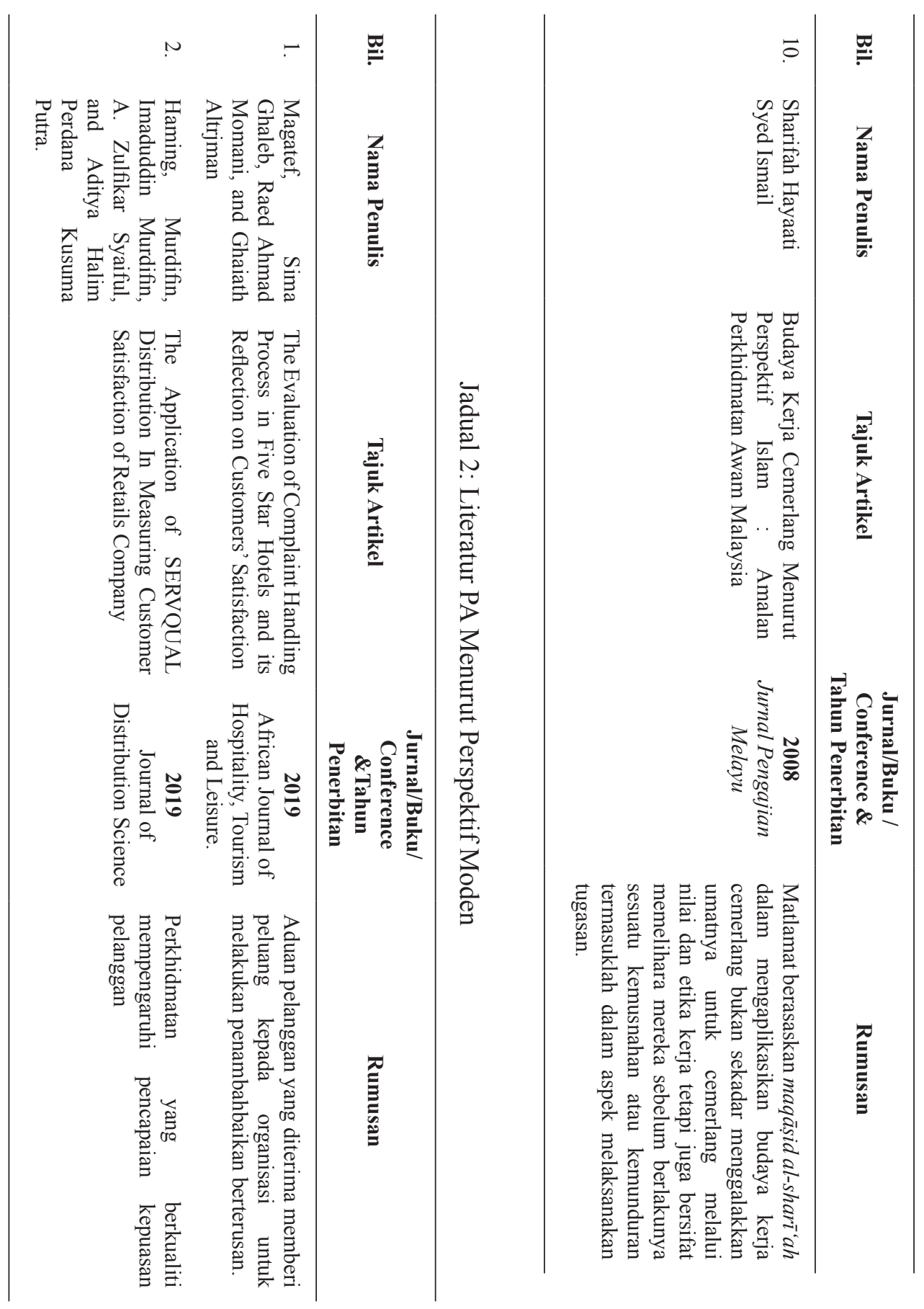


Konsep dan Kepentingan Pengaduan Awam daripada Perspektif Islam dan Moden: Suatu Sorotan Literatur

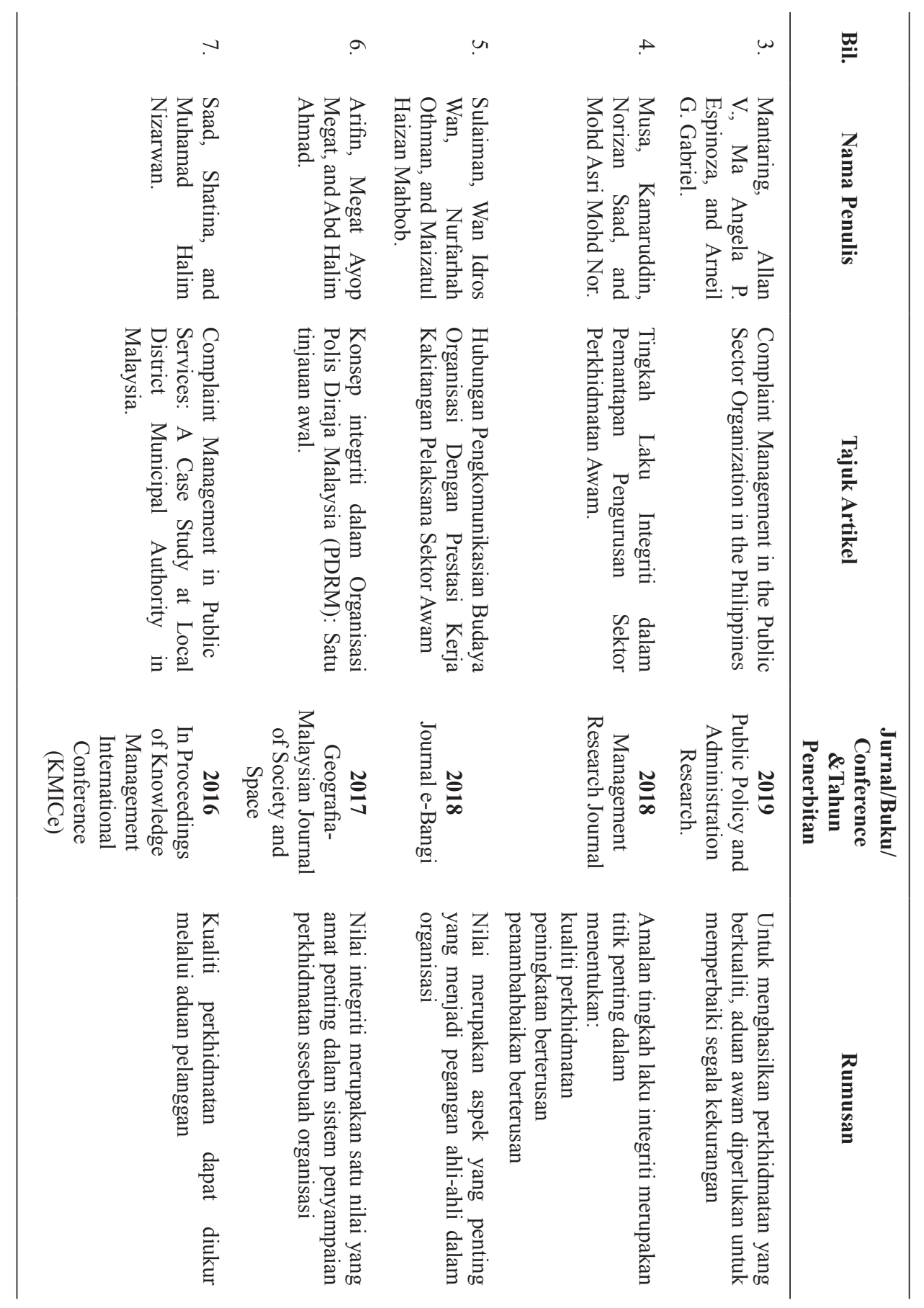


Jurnal Syariah, Jil. 28, Bil. 1 (2020) 31-54

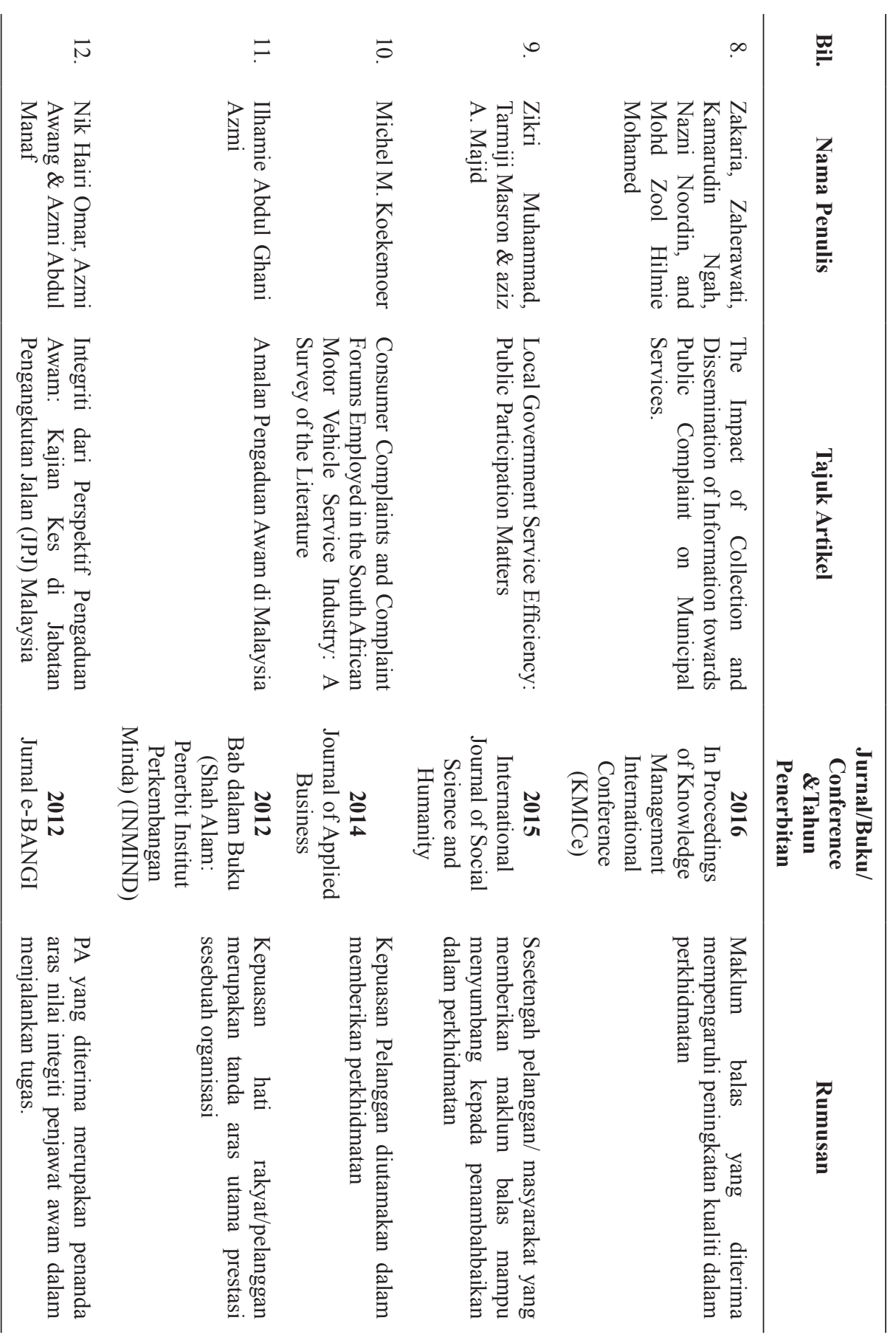




\section{ANALISIS KONSEP PA MENURUT PERSPEKTIF ISLAM DAN MODEN}

Hasil daripada perbincangan daripada kedua-dua perspektif iaitu PA menurut Islam dan moden didapati bahawa terdapat persamaan dan perbezaan yang wujud daripada literatur terdahulu yang membicarakan berkenaan dengan PA (dalam jadual 1 dan 2). Persamaan yang diperolehi daripada keduaduanya adalah daripada aspek definisi konsep, tumpuan nilai dan hubung kait kepentingannya kepada kepuasan pelanggan dan kecekapan organisasi. Kajian lalu sama ada melalui perspektif Islam atau moden membincangkan berkenaan nilai-nilai murni yang lahir daripada pengamalan PA dalam sesebuah organisasi mampu menyumbang kepada nilai amanah dan integriti khususnya kepada penjawat awam atau penyedia perkhidmatan. Perkara ini mampu melahirkan penyedia perkhidmatan yang memiliki sahsiah serta nilai keperibadian yang mulia ketika menjalankan perkhidmatan dalam organisasi. Bezanya, literatur PA menurut perspektif Islam menekankan kepada tanggungjawab semua pihak dalam melaksanakan amar ma 'rūf nahī munkar (AMNM) dan al-shūrā sebagai asas tindakan dan mekanisme bagi memenuhi maqāṣid al-sharī'ah dan mașlahah awam termasuk dalam urusan menerima dan menyelesaikan PA. Penekanan ini menunjukkan bahawa usaha menyelesaikan PA juga termasuk dalam urusan agama. Manakala Literatur PA menurut perspektif moden pula tidak membincangkannya dari perspektif agama sebaliknya mengenengahkan kepentingan PA kepada aspek penghasilan iaitu kepada kualiti perkhidmatan dan kepuasan pelanggan.

\section{KESIMPULAN}

Secara kesimpulannya, daripada 22 sorotan literatur yang dijalankan, dapat difahami bahawa ajaran Islam tidak melarang individu membuat aduan. Bahkan dihukumkan harus dan menjadi fardhu kifayah bagi masyarakat Islam. Islam sangat menggalakkan umatnya untuk sentiasa berbincang bagi mendapatkan kata sepakat dan menyelesaikan kesulitan. Hal yang sama ditekankan dalam literatur moden. Selain daripada itu, dalam literatur Islam juga amat menitikberatkan sesuatu perbuatan itu dilakukan bertujuan untuk mencapai objektif agama, iaitu amar ma'rūf nahī munkar (AMNM) yang bermaksud menyeru kepada perbuatan yang baik dan mencegah daripada perbuatan yang buruk. Pelaksanaan konsep PA menurut perspektif Islam perlulah dengan menepati lima aspek utama, iaitu maqāssid al-sharī'ah (MS), Maṣlaḥah Ammah (MA), amar ma 'rūf nahī munkar (AMNM), al-shūrāa (AS), yang dilaksanakan berasaskan nilai amanah dan bertanggungjawab (NAB). 
Manakala konsep dan kepentingan PA daripada perspektif literatur moden menekankan kepada empat aspek utama, iaitu kepuasan pelanggan (KP1), kualiti perkhidmatan (KP2), nilai integriti (NI) dan usaha ke arah penambahbaikan berterusan (PB). Justeru, dalam melaksanakan pengurusan PA yang berkesan hasil gabungan 22 literatur tersebut, berikut disenaraikan lapan prinsip sebagai garis panduan pelaksanaan PA. Iaitu perlulah PA tersebut;

a) Memenuhi maqāșid al-sharī'ah

b) Memenuhi mașlahah ammah

c) Berasaskan amar ma' 'rüf nahī munkar

d) Berasaskan al-shürā

e) Diuruskan dengan nilai amanah, bertanggungjawab dan integriti

f) Diuruskan dengan memenuhi kepuasan pelanggan

g) Diuruskan bagi memenuhi kualiti perkhidmatan dan

h) Diuruskan bagi tujuan penambahbaikan berterusan.

\section{RUJUKAN}

'Abd al-Wahhāb Khallāf, 'Ilm Usūul al-Fiqh (Kuwait: Dār al-Qalam, 1978).

Abī 'Abd Allāh Muḥammad Ibn Abī Bakr Shams al-Dīn Ibn al-Qayyim alJawziyyah, Turuq al-Hukmiyyah fì al-Siyāsah al-Shar 'iyyah (Bayrūt: Dār al-Kutub al-'Ilmiyyah, 1995).

Abū Dāwud, Sunan Abū Dāwud, vol. 4 (Bayrūt: Dār al-Fikr, t.t.).

Abū Sa'īd 'Abd Allāh Ibn 'Umar Ibn Muḥammad al-Shīrazī al-Bayḍawī, Tafsīr al-Baydawì al-Musammā Anwāar al-Tanzīl wa Asrār al-Ta'wīl, vol. 1 (Bayrūt: Dār al-Kutub al-'Ilmiyyah, 1988).

Bharuddin Che' Pa, 'Pengaduan Awam di Malaysia Menurut Perspektif Siasah Syar'iyyah,' dalam Pengurusan Aduan Menurut Islam, ed. Siti Arni Basir (Shah Alam: Institut Perkembangan Minda (INMIND), 2012), 83105.

Erkoc T.E., 'Bureaucracy and Efficiency,' in Global Encyclopedia of Public Administration, Public Policy, and Governance, ed. Farazmand A. (Cham: Springer, 2017), 1-7.

Haming, Murdifin, Imaduddin Murdifin, A. Zulfikar Syaiful \& Aditya Halim Perdana Kusuma Putra, 'The Application of SERVQUAL Distribution in Measuring Customer Satisfaction of Retails Company,' Journal of Distribution Science (2019): 25-34. 
Hasan Al-Banna Mohamed, Ab Mumin Ab Ghani \& Siti Arni Basir, 'NilaiNilai Sistem Pengurusan Kualiti Islam Berasaskan al-Quran dan Integrasi Ilmu Saintifik, Jurnal Syariah, vol. 23/1 (2015): 25-52.

Hasan al-Banna, Majmū 'ah al-Rasā'il li al-Imām al-Shāhid Hasan al-Banna (Bayrūt: Dār al-Qalam, 1974).

Hasan al-Banna, Risalah Pergerakan Ikhwan al-Muslimin (Solo: Intermedia, 2005).

Ilhamie Abdul Ghani Azmi, 'Amalan Pengaduan Awam di Malaysia,' dalam Pengurusan Aduan Menurut Islam, ed. Siti Arni Basir (Shah Alam: Institut Perkembangan Minda (INMIND), 2012), 127-146.

Kamaruddin Musa, Norizan Saad \& Mohd Asri Mohd Nor, 'Tingkah Laku Integriti dalam Pemantapan Pengurusan Sektor Perkhidmatan Awam,' Management Research Journal, vol. 7 (2018): 260-277.

Karim Zaidan, Masalah Kenegaraan dalam Pandangan Islam (Jakarta: Yayasan al-Amin, 1984).

Kotler, P.T. \& Keller, K.L., Marketing Management (Harlow: Pearson Education Limited, 2016).

Magatef, Sima Ghaleb, Raed Ahmad Momani \& Ghaiath Altrjman, 'The Evaluation of Complaint Handling Process in Five Star Hotels and its Reflection on Customers' Satisfaction,' African Journal of Hospitality, Tourism and Leisure, vol. 8/2 (2019): 1-21.

Mantaring, Allan V., Ma Angela P. Espinoza \& Arneil G. Gabriel, 'Complaint Management in the Public Sector Organization in the Philippines,' Public Policy and Administration Research, vol. 9/2 (2019): 1-26.

Megat Ayop Megat Arifin \& Abd Halim Ahmad, 'Konsep Integriti dalam Organisasi Polis Diraja Malaysia (PDRM): Satu Tinjauan Awal,' Geografia-Malaysian Journal of Society and Space, vol. 12/8 (2017): 136-147.

Mohamad Zaidi Abdul Rahman, 'Kebebasan Bersuara Dari Perspektif Siasah Syar'iyah,' Jurnal Syariah, vol. 9/2 (2001): 103-122.

Mohammad Ghozali \& Nor 'Azzah Kamri, 'Keperibadian Islam dan Profesionalisme dalam Pekerjaan: Satu Analisis Teoritis,' Jurnal Syariah, vol. 23/2 (2015): 255-286.

Muhammad Asad, The Principles of State and Government in Islam (Gibraltar: Dar al-Andalus, 1985). 
Mujar Ibnu Syarif, 'Pengaduan Awam Menurut Perspektif Politik Islam,' dalam Pengurusan Aduan Menurut Islam, ed. Siti Arni Basir (Shah Alam: Institut Perkembangan Minda (INMIND), 2012), 1-30.

Nik Hairi Omar, Azmi Awang \& Azmi Abdul Manaf, 'Integriti Dari Perspektif Pengaduan Awam: Kajian Kes di Jabatan Pengangkutan Jalan (JPJ) Malaysia,' e-BANGI: Jurnal Sains Sosial dan Kemanusiaan, vol. 7/1 (2012): 141-155.

Raja Hishamuddin Raja Sulong, 'Pengaduan Awam Pada Pandangan Cendiakawan Melayu di Zaman Kesultanan Melayu Johor-Riau-Lingga: Fokus Kepada Raja Ali Haji,' dalam Pengurusan Aduan Menurut Islam, ed. Siti Arni Basir (Shah Alam: Institut Perkembangan Minda (INMIND), 2012), 147-175.

Rashad Abdel Monim Mohamed, 'The Method of Handling Customers' Complaints and its Role in Defining Programs of Relations Marketing,' Egyptian Journal of Commercial Studies, vol. 30/2 (2006): 467-555.

Ridzuan Masri, Arman Ahmad \& Razlina Abd Rani, 'Teori Maslow dalam Konteks Memenuhi Keperluan Asas Pekerja dan Peranannya dalam Meningkatkan Prestasi Organisasi: Kajian dan Perspektif Islam,' Jurnal Hadhari, vol. 10, no. 1 (2018): 1-27.

Saad, Shatina \& Muhamad Halim Nizarwan, 'Complaint Management in Public Services: A Case Study at Local District Municipal Authority in Malaysia,' (Proceedings of Knowledge Management International Conference (KMICe), Chiang Mai, Thailand, 29-30 August 2016).

Sharifah Hayaati Syed Ismail \& Nor 'Azzah Kamri, 'Teras Pengurusan Islam,' dalam Pengurusan Aduan Menurut Islam, ed. Siti Arni Basir (Shah Alam: Institut Perkembangan Minda (INMIND), 2012), 31-57.

Sharifah Hayaati Syed Ismail, 'Budaya Kerja Cemerlang Menurut Perspektif Islam: Amalan Perkhidmatan Awam Malaysia,' Jurnal Pengajian Melayu, vol. 19/1 (2008): 187-207.

Al-Shāțib̄i, al-I 'tișām min al-Kutub, vol. 3 (Qāhirah: al-Maktabah al-Tijāriyyah al-Kubrā, 1975).

Shaykh Muḥammad Ibn Șāliḥ al-'Uthaymīn, Sharh al-Arba 'ìn al-Nawawiyyah, terj. Abu Ahsan Sirojuddin Hasan Bashri (Jakarta: Pustaka Ibnu Kathir, 2009).

Siti Arni Basir \& Musaiyadah Ahmadun, 'Prinsip-Prinsip Pengurusan Pengaduan Awam Dari Perspektif Islam,' dalam Pengurusan Aduan Menurut Islam, ed. Siti Arni Basir (Shah Alam: Institut Perkembangan Minda (INMIND), 2012), 59-82. 
Sulaiman, Wan Idros Wan, Nurfarhah Othman \& Maizatul Haizan Mahbob, 'Hubungan Pengkomunikasian Budaya Organisasi Dengan Prestasi Kerja Kakitangan Pelaksana Sektor Awam,' e-Bangi, vol. 14, no. 3 (2018): 1-18.

The Saudi Investment Bank, Sustainability Report (Saudi Arabia: The Saudi Investment Bank, 2013).

Zakaria, Zaherawati, Kamarudin Ngah, Nazni Noordin \& Mohd Zool Hilmie Mohamed, 'The Impact of Collection and Dissemination of Information towards Public Complaint on Municipal Services,' (Proceedings of Knowledge Management International Conference (KMICe), Chiang Mai, Thailand, 29-30 August 2016).

Zikri Muhammad, Tarmiji Masron \& Aziz A. Majid, 'Local Government Service Efficiency: Public Participation Matters,' International Journal of Social Science and Humanity, vol. 5/10 (2015): 827-831. 
Jurnal Syariah, Jil. 28, Bil. 1 (2020) 31-54 